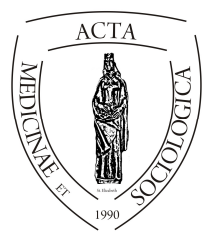

\title{
A lakhatás és a háztartások felszereltségének változásai a panelkutatások eredményei alapján
}

\author{
Szoboszlai Katalin ${ }^{1}$ \\ ${ }^{1}$ főiskolai docens, Debreceni Egyetem Egészségügyi Kar, 4400 Nyíregyháza, Sóstói út 2-4.
}

\section{INFO}

Szoboszlai Katalin

szoboszlai.katalin@foh.unideb. hu

\section{Keywords}

quailty of life, housing, rental apartment, housing poverty

\section{ABSTRACT}

Changes in housing and household equipment based on panel research results. Quality of Life in Nyíregyháza Household Panel Research started ten years ago in Nyíregyháza. The various aspects of local housing have been analyzed in each survey. The results of the most recent 2018 data collection as well as their comparison with data from previous data collections are presented in this paper. Slight changes could be observed in the statistical analysis of dwelling and housing compared to previous surveys. There are changes in the number of flats and local government-owned rental apartments, in the type of ownership, in the planning and realization of restoration. Housing poverty and the relatively low number of social rental apartments are still considerable. Rental apartments of local government do not meet the demands, the social network that would provide safe housing is not enough for people who cannot afford to buy own property or to rent a house or a flat offered by the market.

Kulcs szavak
életminőség,
lakhatás,
bérlakás,
lakhatási szegénység

Absztrakt. Nyíregyháza életminősége - Háztartáspanel kutatás tíz évvel ezelőtt kezdődött Nyíregyházán. A lokális lakásjellemzők és a lakhatás különféle aspektusainak elemzését minden adatfelvételnél elvégeztem. Jelen tanulmányban ismertetem a legutóbbi, 2018-as adatfelvétel eredményeit és ezeket összehasonlítom a megelőző adatfelvételek adataival. A lakás és lakhatás statisztikai elemzési területein kevés változás tapasztalható a korábbi adatfelvételekhez képest. Elmozdulás kis mértékben inkább a lakások és az önkormányzati bérlakások számának alakulásában, a tulajdonosi jellegben, a felújítás tervében és megvalósulásában tapasztalható. A lakhatási szegénység, a szociális bérlakások relatíve alacsony száma továbbra is számottevő. Az önkormányzati bérlemények nem elégítik ki az igényléseket, kevésnek bizonyul az a háló, ami a tulajdonra szert tenni nem 
képes és piaci bérleményt megfizetni sem képes réteget

biztonságos lakhatásban tartja.

Ez a tanulmány a Nyíregyháza város életminősége - Háztartáspanel kutatás Egészségi állapot felmérése keretében készült.

\section{Bevezetés}

Nyíregyháza életminősége - Háztartáspanel kutatás tíz évvel ezelött kezdődött Nyíregyházán. A lokális lakásjellemzők és a lakhatás különféle aspektusainak elemzését minden adatfelvételnél elvégeztem. Jelen tanulmányban ismertetem a legutóbbi, 2018-as adatfelvétel eredményeit és ezeket összehasonlítom a megelöző adatfelvételek adataival. (Huszti és mtsai, 2018) A lakás és lakhatás statisztikai elemzési területein kevés változás tapasztalható a korábbi adatfelvételekhez képest. Elmozdulás kis mértékben inkább a lakások és az önkormányzati bérlakások számának alakulásában, a tulajdonosi jellegben, a felújítás tervében és megvalósulásában tapasztalható. A lakhatási szegénység, a szociális bérlakások relatíve alacsony száma továbbra is számottevő. Az önkormányzati bérlemények nem elégítik ki az igényléseket, kevésnek bizonyul az a háló, ami a tulajdonra szert tenni nem képes és piaci bérleményt megfizetni sem képes réteget biztonságos lakhatásban tartja.

\section{Tulajdon, lakásbérlés}

A lakosok 82,6\%-a a saját tulajdonú lakásában él 2018-ban ${ }^{1}$. Az előző adatfelvételhez képest 4,5\%-kal csökkent a saját tulajdonú lakásban élők aránya. A csökkenés kismértékben betudható annak, hogy a devizahiteles lakástulajdonosok lakásainak 0,41\%-a a Nemzeti Eszközkezelö tulajdonába került. A lakásbérlők aránya az elmúlt három évben csökkent. 2018-ban a lakosok 9,72\%-a él bérleményben, közülük csupán 1,22\%-a szociális bérlakásban. Szembetünő a csökkenés az önkormányzat kezelésében lévő szociális bérlakásban élők számát tekintve, ahol az előző adatfelvétel óta $0,7 \%$-kal csökkent a bérlők száma. Láthatóan megemelkedett viszont a szívességi lakáshasználók aránya, 2018-ban a lakosok 3,67\%-a más tulajdonában lévő lakásban él szívességi befogadottként. (1. sz. táblázat)

A 2018-as adatfelvételkor megkérdezettek 53\%-a rendelkezett saját tulajdonú lakással életében. A lakások tulajdonjoga eladással vagy elveszítéssel került el a lakosoktól, aminek okai változatosak, ezek közül néhányat példaként említek meg: költözés, a lakás lakhatatlanná vált, a lakás értékesítése válás miatt, új és nagyobb lakás vásárlása, hitel, banki tartozás, stb. Hazánkban erősen tartja magát a tulajdonosi személet a lakhatásban. A tulajdonszerzés érdekében lakáshitel, valamennyi önerő és a családi otthonteremtési kedvezmény (korábban lakáscélú szociálpolitikai támoga-

\footnotetext{
${ }^{1}$ A lakás és lakhatással kapcsolatos kérdéseknél a minta elemszáma 504 fó, esetlegesen az egyes kérdéseknél az ettől eltérő válaszadást jelölöm.
} 
tás) igénybevétele mozgósítható. A családok jogi és pénzügyi kockázatvállalást is hajlandóak megtenni a tulajdonszerzés érdekében, amely kockázat kimenetele lakásvesztéssel járhat. Az előző adatfelvételhez képest új elem a Nemzeti Eszközkezelő tulajdonában lévő lakások megjelenése a lakásstatisztikában. Ezeknek a lakásoknak a tulajdona a lakáscélú hitelt visszafizetni nem képes adósoktól került át a Nemzeti Eszközkezelő Zrt-hez. A korábbi lakástulajdonosok szerződéssel, bérlőként élnek tovább a lakásokban, akik a jelzáloghitel-szerződés megkötésekor megállapított forgalmi érték 1,5\%-ának egytizenketted részét fizetik ki havonta lakbérként ${ }^{2}$.

\begin{tabular}{|l|c|c|}
\hline & Nyíregyháza & Nyíregyháza \\
& 2015 & 2018 \\
\hline Saját tulajdon & 87,1 & 82,6 \\
\hline Bérelt lakás & 8,0 & 8,57 \\
\hline Önkormányzati bérlemény & 1,9 & 1,22 \\
\hline Más tulajdona (szívességi lakáshasználat) & 1,2 & 3,67 \\
\hline Nemzeti Eszközkezelö Zrt. tulajdonában van & - & 0,41 \\
\hline Egyéb & 1,8 & 3,47 \\
\hline
\end{tabular}

Forrás: Nyíregyháza Életminősége, 2015 és 2018

1. sz. táblázat: Lakások tulajdonosi jellemzői (\%).

\section{Önkormányzati bérlakásban élők}

A lakosok 6,5\%-a adott be szociális bérlakásra igényt az önkormányzathoz. A legtöbben, az igénylők 18\%-a 1997-ben nyújtotta be kérelmét az önkormányzathoz. 1997-et megelőző és követő években egyenletesen 9\% a bérlakást igénylők aránya. (1. sz. diagram)

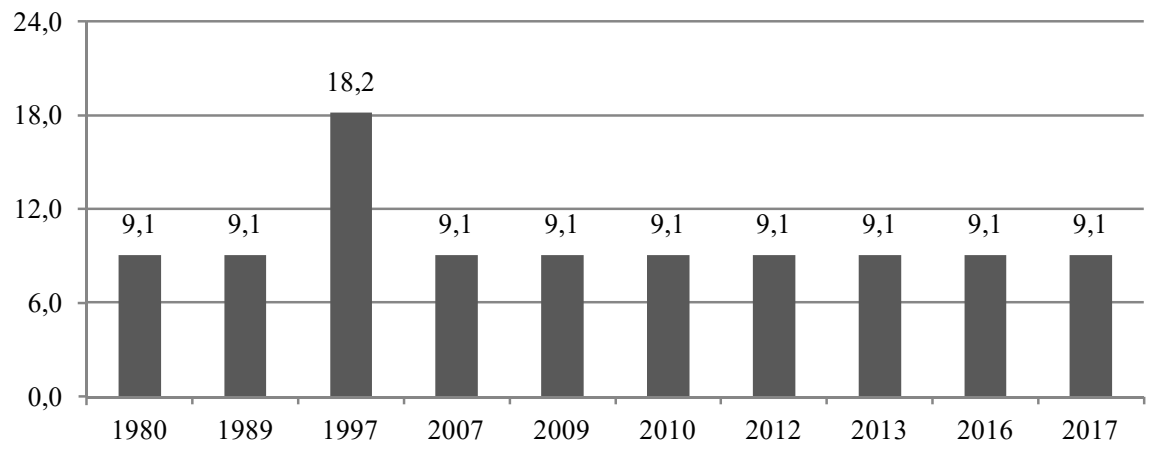

Forrás: Nyíregyháza Életminősége, 2018

1. sz. diagram: Önkormányzati bérlakás iránti igényt benyújtók aránya 1980 és 2017 között $(\%)$.

${ }^{2}$ Forrás a 128/2012. (VI. 26.) Korm. rendelet a Nemzeti Eszközkezelő Zrt. működésével kapcsolatos egyes szabályokról, 5§ (1); http://www.netzrt.hu/?page_id=53 
A Nyíregyházán található önkormányzati bérlakások száma csökkenést mutat. A KSH területi statisztika adatok alapján az önkormányzati bérlakásállomány változása negatív, 2008 és 2016. között 5,4\%-kal csökkent, vagyis 108 lakással kevesebb önkormányzati bérlakás áll az igénylők rendelkezésére Nyíregyházán. (2. sz. táblázat) A kevesebb önkormányzati bérlakással megnő az esélye, hogy a lakhatás peremén élők száma emelkedik. Mindazoknak, akiknek relatíve alacsony jövedelme és hitelképtelensége nem teszi lehetővé a tulajdonszerzést és azoknak, akik nem tudják megfizetni a piaci albérleti árakat átmeneti lakhatásként a rokoni befogadás, a szívességi elszállásolás müködik, azonban az ilyen típusú lakhatásban élöket jogi szerződés és garancia nem védelmezi, ezért ezek a lakhatási formák meglehetősen bizonytalanok. A rokoni, szívességi jellegü lakhatás megszünésének gyakori oka a lakásban élők közötti konfliktus, aminek következményei között számolhatunk a hajléktalansággal.

\begin{tabular}{|c|c|c|c|c|c|}
\hline Település & $\begin{array}{c}\text { Önkormány- } \\
\text { zati bérlaká- } \\
\text { sok száma } \\
\text { 2008-ban }(\mathrm{db})\end{array}$ & $\begin{array}{c}\text { Önkormányza- } \\
\text { ti bérlakások } \\
\text { száma 2016- } \\
\text { ban }(\mathrm{db})\end{array}$ & $\begin{array}{c}\text { Önkormányza- } \\
\text { ti bérlakások } \\
\text { számának } \\
\text { változása, } \\
2008-2016 \\
(\mathrm{db})\end{array}$ & $\begin{array}{c}\text { Önormányza- } \\
\text { ti bérlakásállo- } \\
\text { mány változá- } \\
\text { sa, 2008-2016 } \\
(\%)\end{array}$ & $\begin{array}{c}\text { Önormányza- } \\
\text { ti bérlakások } \\
\text { aránya a tele- } \\
\text { pülés lakásai } \\
\text { között, } 2016 \\
(\%)\end{array}$ \\
\hline Nyíregyháza & 2001 & 1893 & -108 & $-5,4$ & 3,65 \\
\hline
\end{tabular}

Forrás: TeIR; KSH - T-STAR, BP-STAR, 2016

2. sz. táblázat: A bérlakásállomány változása, Nyíregyházán 2008-2016 között.

Az önkormányzati bérlakásokat kezelő cég adatai alapján a bérlakásállomány száma 1900 darab alá csökkent 2016-ban. A lakásszám meredeken csökken, 2016-hoz képest 54 darabbal kevesebb 2018-ban, miközben hiányzik a megszünt lakások új építéssel történő pótlása. (2. sz. diagram)

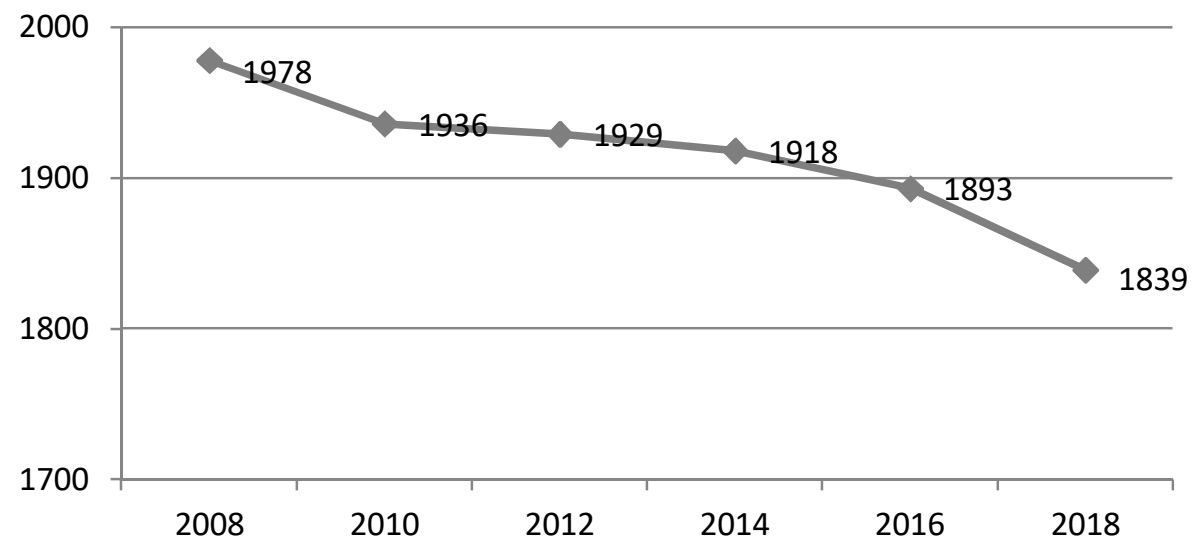

Forrás: Nyíregyházi Városüzemeltető és Vagyonkezelő Kft., 2018.

2. sz. diagram: Önkormányzati bérlakások száma 2008 és 2018. között Nyíregyházán (db). 
A városi vagyonkezelö cég nyilvántartása alapján 5526 fö lakik önkormányzati bérlakásban, ami nem jelent minden esetben valós adatot, mivel előfordul, hogy a bérlők nem jelentik be a bérlakásba beköltöző és onnan elköltöző személyeket. A szociális alapon önkormányzati bérlakásban élők jövedelme munkaviszonyból, családtámogatási ellátásból, álláskeresési támogatásból, nyugellátásból származik. Jelenleg 1883 fő a nyilvántartott lakásigénylők száma. (Nyíregyházi Városüzemeltető és Vagyonkezelő Kft., 2018.)

Közel kétezer bérlakás igénylőnek nem tud az önkormányzat bérlakást kiutalni. A bérlakásban élők 34\%-ánának megfelelő új igénylőt tartanak nyilván a Nyíregyházi Városüzemeltető és Vagyonkezelő Kft-nél. Ebből adódóan az önkormányzati bérlakás állományt tekintve a jelenlegihez képest, figyelembe véve az elhasználódást, 5 éven belül 30-35\%-os bérlakás szám növekedés indokolt lenne.

Az alsó jövedelmi ötödbe tartozó háztartások az albérletpiacról kiszorulnak, ha mégis találnak maguknak megfizethető lakhatást, akkor azok a lakások rossz minőségben és külterületen találhatók. 2013-tól az albérletárak meredeken emelkednek az országban. A lakásbérleti díj és lakhatáshoz kapcsolódó kiadások megfizethetősége az átlagjövedelem alatt élöknek komoly terhet jelent, a háztartás bevételének $50 \%$-át is elérheti.

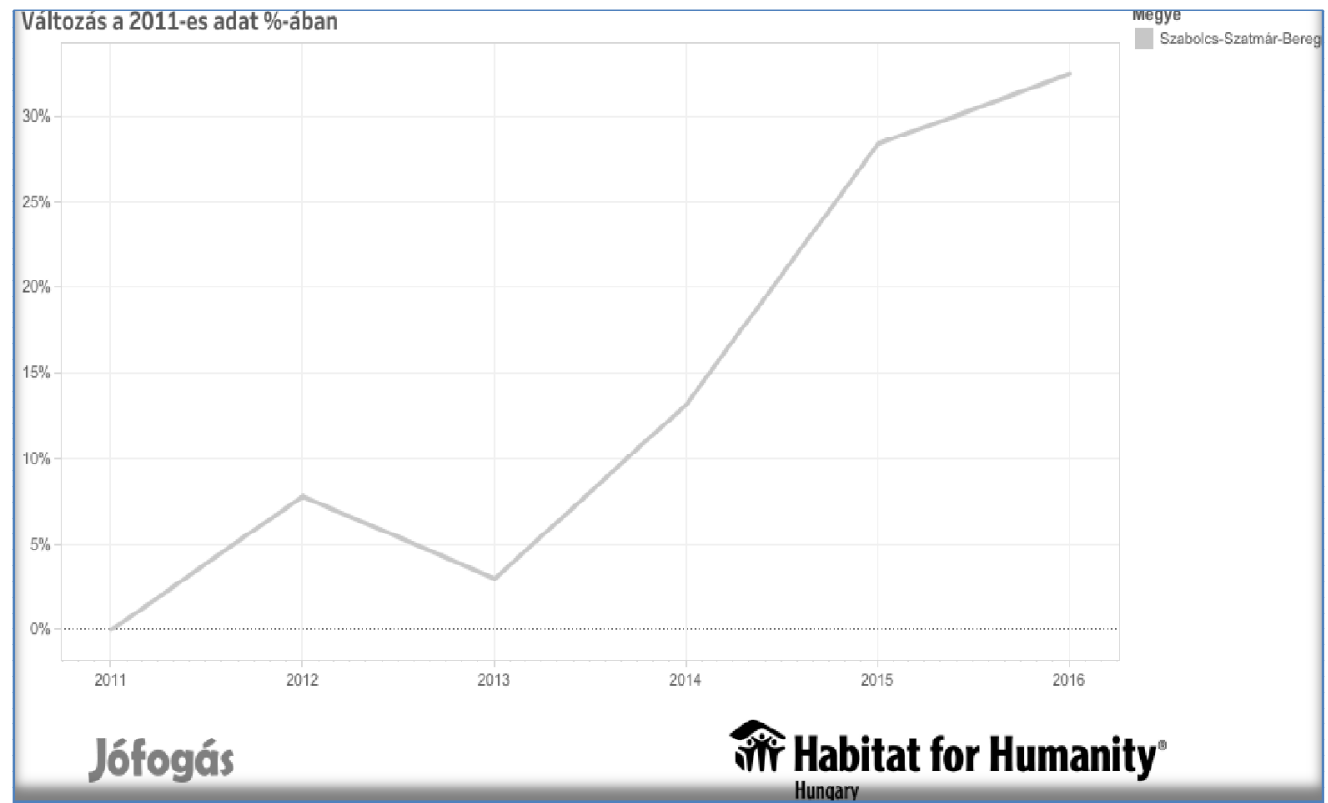

Forrás: Habitat for Humanity, 2018.

1. sz. ábra: 40 nm-es lakásbérleti díja a regionális átlagjövedelem százalékában Szabolcs Szatmár-Bereg megyében ${ }^{3}$.

3 Az alkalmazásban állók havi nettó átlagkeresete Szabolcs-Szatmár-Bereg megyében 151.000 forint 2018-ban. KSH, 2018. Látogatva: 2018. november 29. Letöltés helye:http://www.ksh.hu/docs/hun/xstadat/xstadat_evkozi/e_qli030b.html 
Az 1. sz. ábra fenti diagram jól szemlélteti a piaci áron kiadásra kerülő albérletárak hirtelen növekedését 2013 után Szabolcs-Szatmár-Bereg megyében. Az adatokat bizonyára a nyíregyházi lakásbérleti árak emelkedése húzza felfelé. A megyeszékhelyen, 2018. októberben az albérleti díj átlagára havonta $1604 \mathrm{Ft} / \mathrm{nm}^{4}$ volt, ez egy 40 nm-es lakás esetében havi $64.160 \mathrm{Ft}$ albérleti díjat jelent, amihez további kiadásként adódik a rezsiköltség.. A Policy Agenda létminimum számítása alapján az egy fơre számított létminimum 2017-ben 90.400 Ft havonta ${ }^{5}$, amit alapul véve egy minimálbér jövedelemből élö felnőtt embernek az önfenntartás veszélyeztetése nélkül piaci áron albérletet fenntartani képtelenség.

A saját tulajdonú lakással nem rendelkező, létminimum jövedelemből élőknek komfort alatti minőségü lakásbérlés, családtagokkal való együttélés és szívességi befogadás jelent lakhatási lehetőséget. A létminimum alatti jövedelemből élők vannak kitéve leginkább a lakhatás elveszítésének anyagi nélkülözés miatt. Számukra a lakhatáshoz kapcsolódó költségek kifizetése az alapszükségletek kielégítésének kárára valósítható meg. Kényszerü választás eredménye a létfenntartáshoz szükséges élelmiszer, ruhanemü, gyógyszer kiadások fedezése versus a lakhatás költségeinek fizetése, amiröl a létalatti jövedelemböl élők lemondani kényszerülnek pénz hiányában.

Mindent összevetve a létminimumból vagy az alatti jövedelemből élő egyszemélyes és több személyes, gyerekes háztartásoknak reális lakhatási alternatívaként az önkormányzati szociális bérlakások jelentenek biztonságos és kiadásokban is vállalható lakhatási formát.

\section{Az önkormányzati bérlakások minősége}

Az önkormányzati bérlakások 68\%-a összkomfortos, ezzel szemben $14 \%$-a komfortos és $18 \%$-a komfort alatti besorolású. Komfort nélküli önkormányzati bérlakások a Keleti lakótelepen, félkomfortos lakások elsősorban Huszár lakótelepen és a szórványosan elhelyezkedő családi ház jellegü épületekben találhatók. Komfortos és összkomfortos lakások a város egész területén találhatóak. (3. sz. diagram)

A legrosszabb minőségü önkormányzati bérlakások nagy része a város két jelentősebb szegregátumában található. A Keleti lakótelep lakásaiban élő bérlők telepről történő elköltözése napirenden van, ezek a komfortnélküli lakások felszámolásra kerülnek a kiköltözések után. A Huszár lakótelep lakásainak felújítása folytatódik, a bérlők a mostaninál jobb múszaki állapotban lévő lakásokban élnek a felújítások befejezését követően. (3. sz. táblázat)

\footnotetext{
${ }^{4}$ Forrás: https://www.ingatlannet.hu/statisztika/Ny\%C3\%ADregyh\%C3\%A1za

${ }^{5}$ Forrás: https://www.policyagenda.hu/elemzesek/2018/letminimum-es-tarsadalmiminimum-2017-ben/\#more-16433
} 


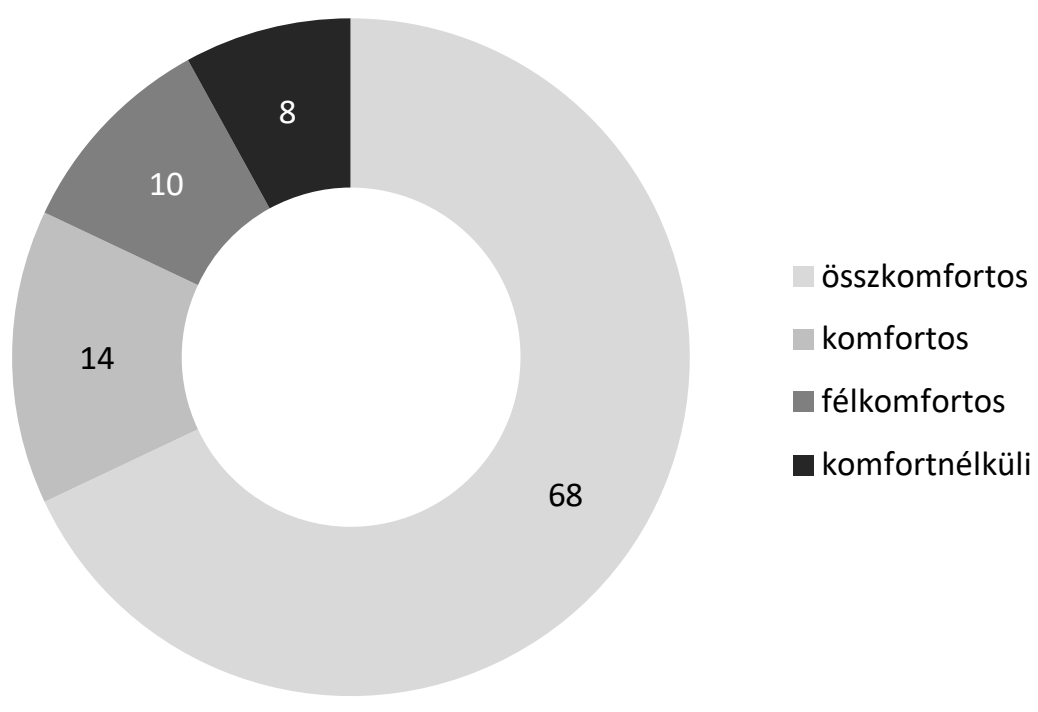

Forrás: Nyíregyházi Városüzemeltető és Vagyonkezelö Kft., 2018.

3. sz. diagram: Önkormányzati bérlakások komfortfokozata Nyíregyházán (\%)

\begin{tabular}{|l|c|}
\hline \multicolumn{1}{|c|}{ Megnevezés } & Átlag \\
\hline A háztartásban élők száma & 2,78 fö \\
\hline A lakásban található szobák száma & 2,75 szoba \\
\hline A lakás alapterülete & 80 négyzetméter \\
\hline
\end{tabular}

Forrás: Nyíregyháza Életminősége, 2018

3. sz. táblázat: A nyíregyházi önkormányzati bérlakásokra vonatkozó alapadatok.

\section{A lakásállomány állapota}

A lakosok 14\%-a szerint a lakásnak, amelyben él van olyan hibája, ami a mindennapi életet megnehezíti. Ezek a hibák jellemzően a következők: a lakás vizes, gombás, sötét, zajos és dohos. Az egészségre ártalmas lakások mellett a lakosok olyan kellemetlenségekről is beszámoltak, amelyek a lakások komfortosságában jelentenek hiányosságokat, mint például felújításra, ablak cserére, festésre lenne szükség vagy nincs lift a házban, probléma van a fütéssel vagy éppen a vízvezetékkel. Ezek a problémák hosszú évek óta fennállnak, az érintett lakosok sok esetben jövedelmükből nem tudják kifizetni a lakások rossz állapotának javítását. A huzatos ablak, a rosszul müködö kályha, konvektor következménye a megnövekedett energiafogyasztás. Télen több tüzelöre, fütési energiára van szükség, növekszik a ráfordított költség, aminek kifizetése ugyancsak terheket jelent a háztartásoknak. 


\section{Lakásfelújítás}

A lakásfelújitás átlagos ideje 4,5 év, vagyis ennyi idő telik el, amíg a lakásban kisebb - nagyobb mértékü munkákat elvégeznek.

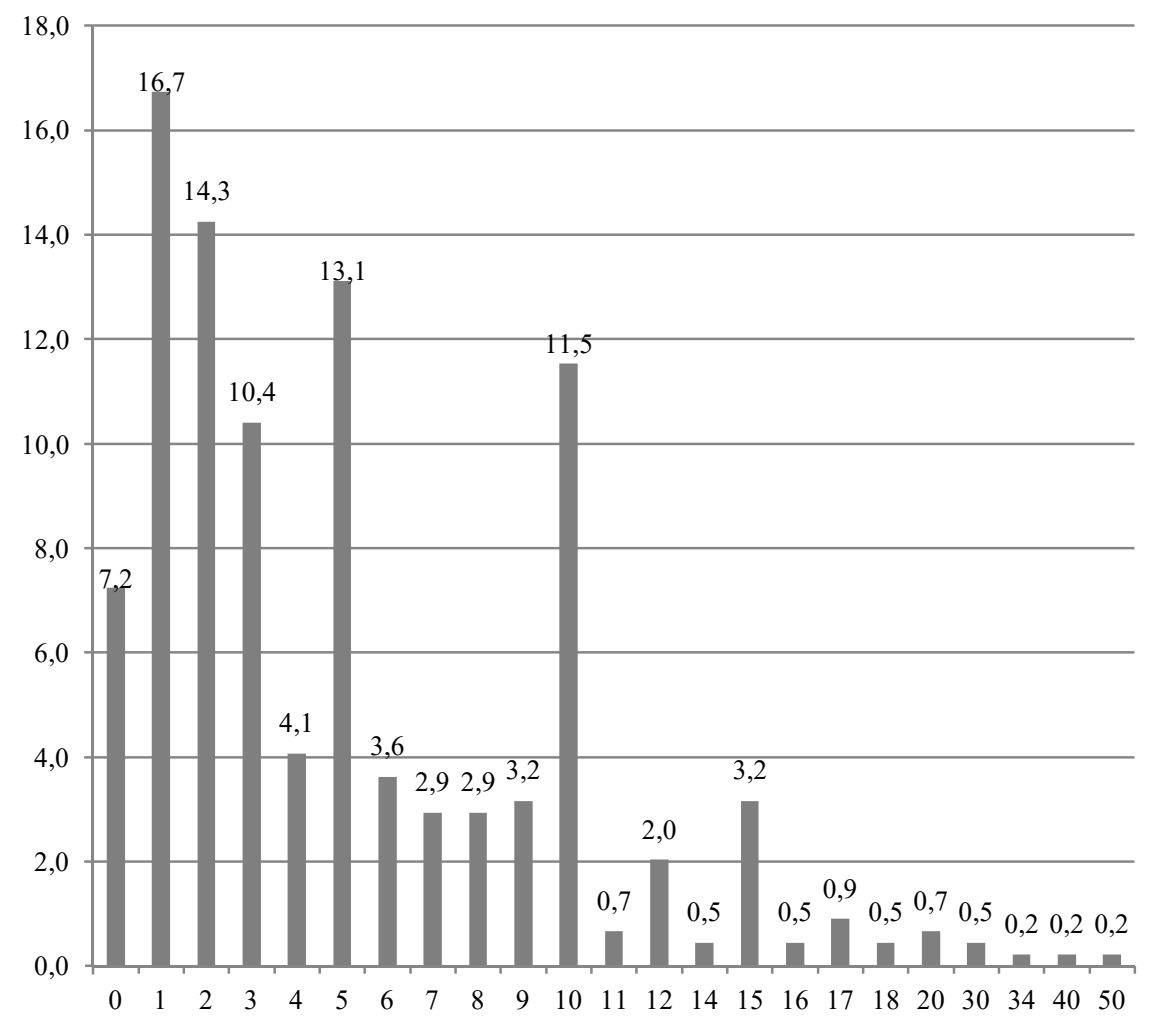

Forrás: Nyíregyháza Életminősége, 2018

4. sz. diagram: Hány évvel ezelőtt volt felújítás utoljára a lakásban? (\%) N=442.

A lakások 7\%-a soha nem volt felújítva a városban. A lakások 59\%-ánál volt valamilyen felújítás az elmúlt öt évben. A felújítás általában nem teljes lakásfelújitásról szól, hanem a lakás egy-egy területe újul meg vagy tartozékának cseréjére, felújitására kerül sor. Ezek jellemzően: festés, nyílászáró csere, fürdőszoba felújítás, burkolat csere, bútorvásárlás. (4. sz. diagram)

Az 1 millió forint alatti lakásfelújításokból arra következtethetünk, hogy ezekben a lakásokban élők alacsony költségigényü felújításokat végeztek el a lakásokban. Ez állagmegóvást, a lakás egy részének megújulását és korszerüsítését jelenti, de számottevően nem növeli meg a lakás értékét. (5. sz. diagram) 


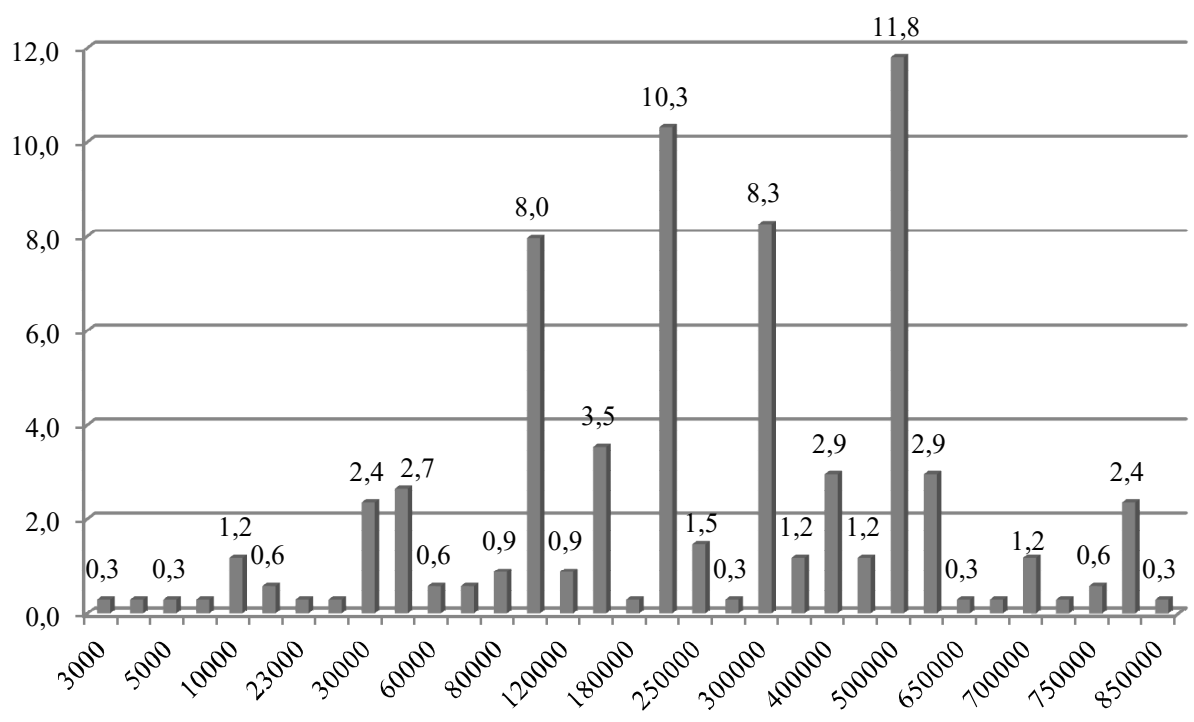

Forrás: Nyíregyháza Életminősége, 2018

5. sz. diagram: 1 millió forint alatti lakás felújítási költségek alakulása (\%) N=339.

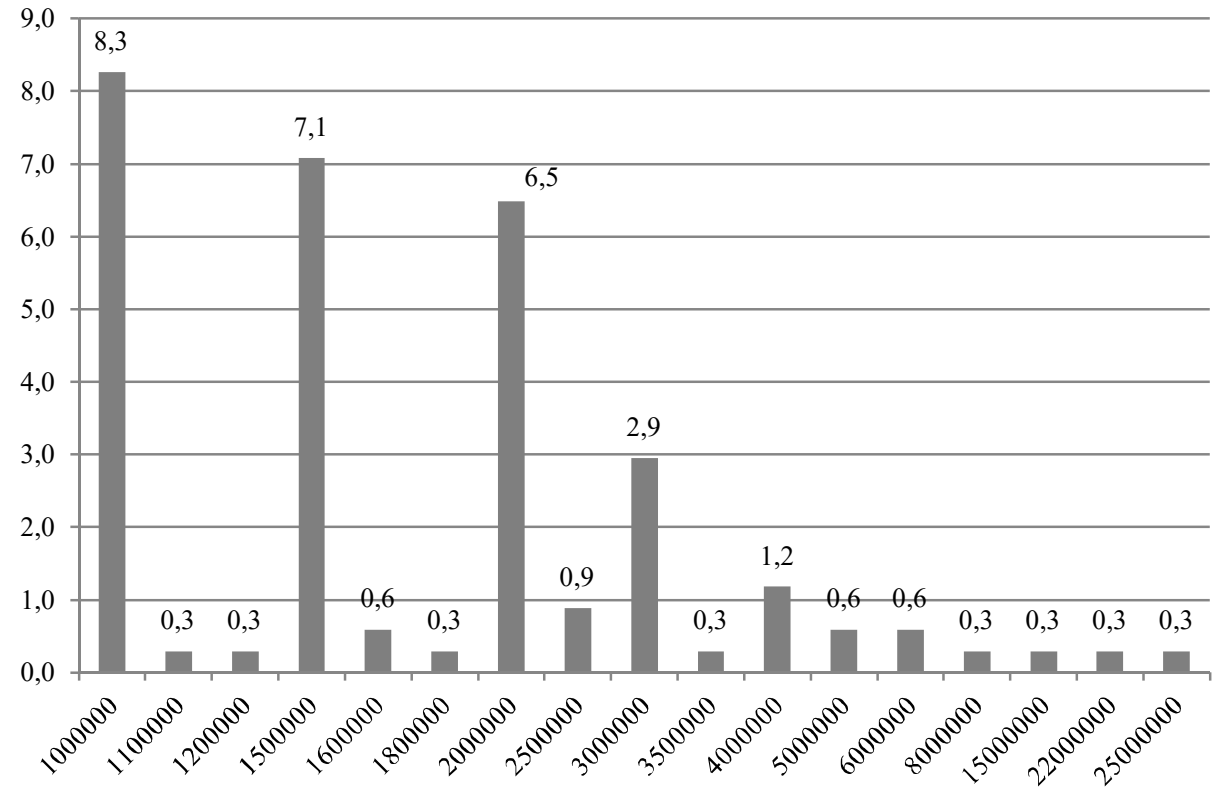

Forrás: Nyíregyháza Életminösége, 2018

6. sz. diagram: 1 millió forint feletti lakás felújítási költségek alakulása (\%) N=339.

Az 1 millió forint feletti költségü lakásfelújítások esetében a költségek alakulása a teljes felújítás és korszerüsítés költségeire mutatnak rá. A lakások $30 \%$-ánál volt 1 
millió forintot meghaladó lakásfelújítás, míg a lakások 10\%-nál a felújítási költség 20 és 30 millió forint közé esett. (6. sz. diagram)

A lakosság 16\%-a nem tartja időszerünek lakásának felújítását. Azok, akik felújítanának, de jelenleg nem tudnak rá költeni a következő munkák elvégzését tartják szükségszerünek: festés, nyílászáró csere, fürdőszoba felújítás és villanyvezeték csere.

\section{Problémák a lakókörnyezetben}

A lakókörnyezeti problémák tekintetében hasonló válaszokat kaptunk, mint az előző adatfelvételekben. A lakosok válaszai alapján a hangos és zajos lakókörnyezet jelenti a legtöbb gondot. A lakosok egyötöde problémaként éli meg a környezeti zajokat az otthonában.

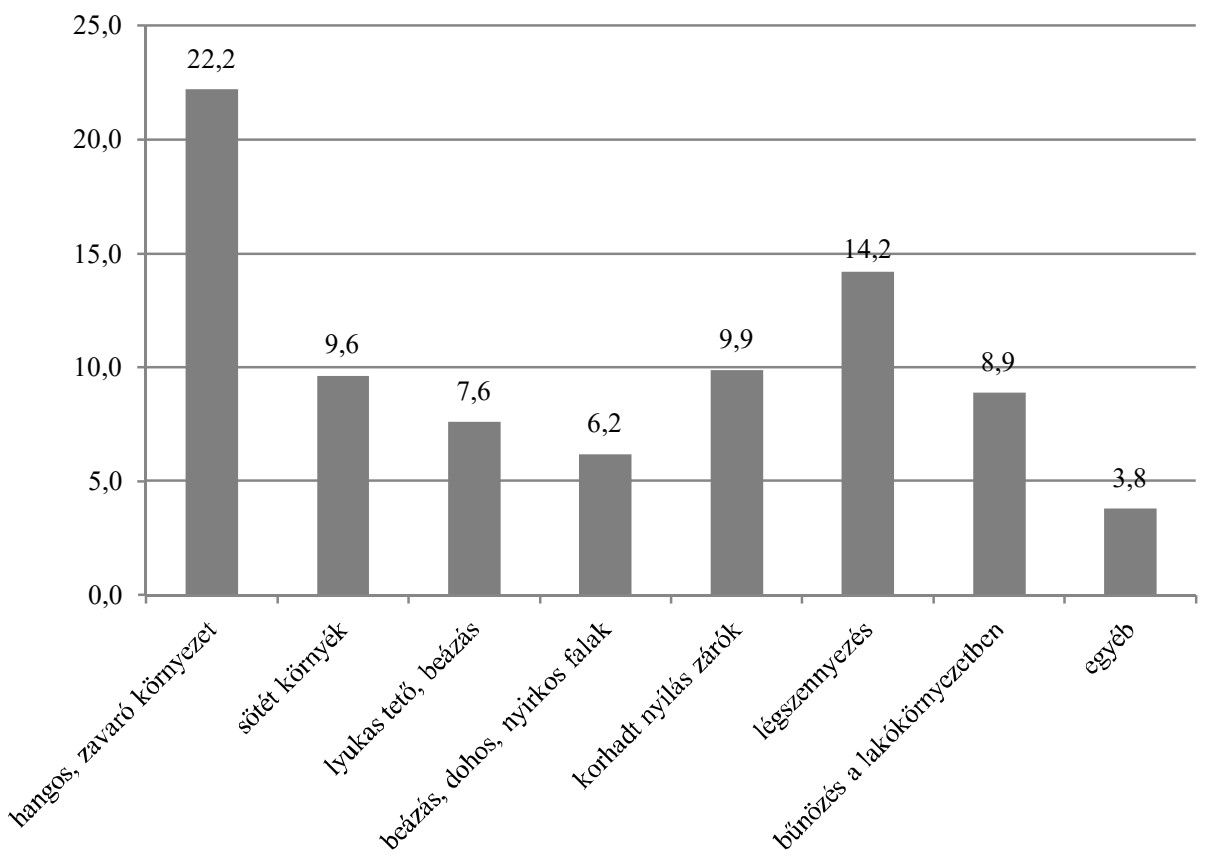

Forrás: Nyíregyháza Életminösége, 2018

7. sz. diagram: Problémák a lakókörnyezetben (\%).

Második helyre a légszennyezés, harmadikra a korhadt nyílászáró került, és mindezek után következik a sötét környék és bünözés jelenléte a lakókörnyezetben. A légszennyezés egészségre káros határértéke különösen télidőben a rossz fütési módnak köszönhetően megemelkedik. A lyukas tető, a beázás, a korhadt nyílászárók szükségessé teszik azok javítását, cseréjét. Amennyiben ezek a munkák elmaradnak, romlik a lakás állapota, megnövekszik a fütési költsége. (7. sz. diagram) 


\section{Tartós fogyasztási cikkek a háztartásokban}

A tartós fogyasztási cikkek esetében a müszaki és az informatikai eszközöket tekintve kisebb átrendeződés tapasztalható. A háztartási eszközök közül a hütőszekrény minden háztartásban megtalálható, és szinte mindenhol találunk színes televíziót, mikrohullámú sütőt és mosógépet.

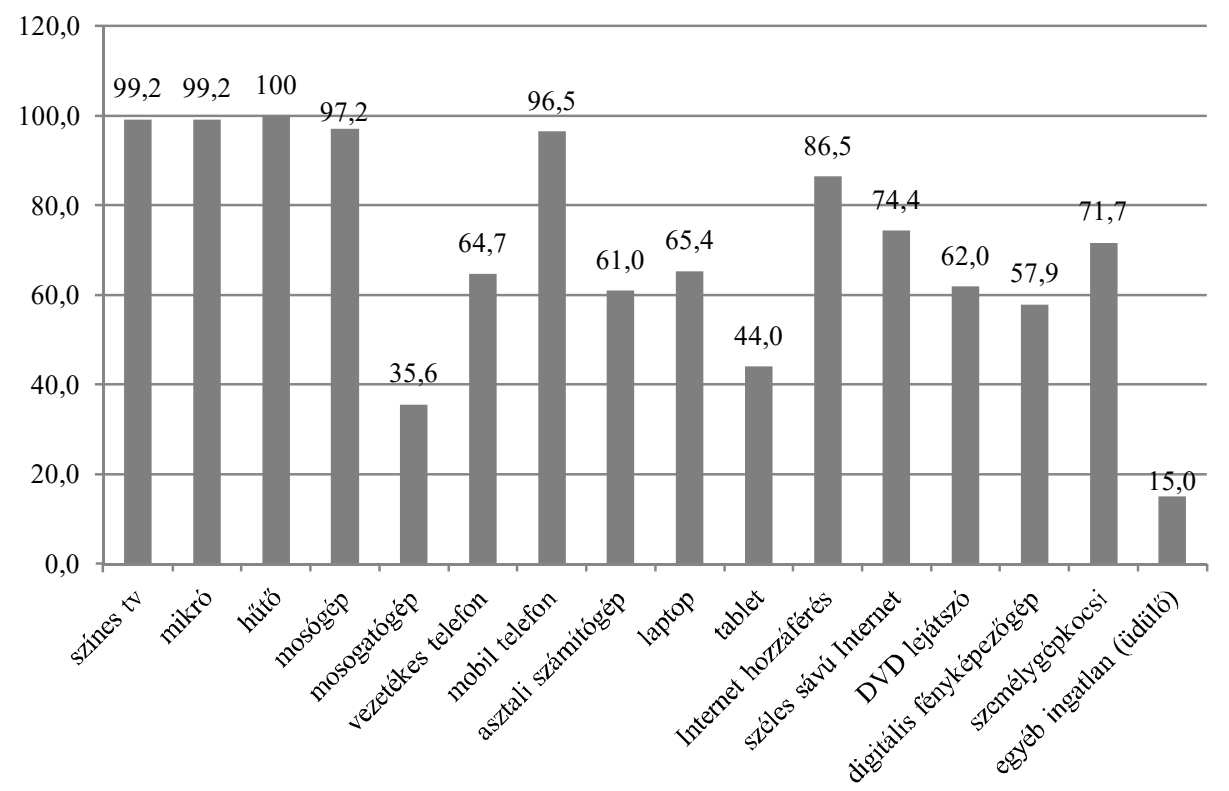

Forrás: Nyirregyháza Életminösége, 2018

8. sz. diagram: Tartós fogyasztási cikkek a háztartásokban (\%) N=494.

Az informatikai eszközök közül majdnem minden háztartásban van mobil telefon és a háztartások megközelítően kétharmada rendelkezik asztali személyi számítógéppel, laptoppal. Az informatikai eszközök elterjedése szükségszerűen megnövelte a vezetékes és mobil internettel rendelkező háztartások arányát. Internet hozzáférés a háztartások 86,5\%-ában, széles sávú internet pedig 74,4\%-ában van, ami határozottan növekedést mutat az előző adatfelvételhez képest. A háztartások közel háromnegyedében találunk személygépkocsit. Az egyéb digitális eszközök, mint DVD lejátszó és fényképezőgép hozzávetőleg a háztartások 60\%-ában megtalálható. (8. sz. diagram)

Az elmúlt tíz évben szinte minden kategóriában bővülés figyelhető meg a lakások felszereltségében. Kivétel a vezetékes telefon és a digitális fényképezőgép, ahol a csökkenés ellensúlyozója a mobiltelefonok és internetezésre alkalmas okos eszközök számának növekedése. 


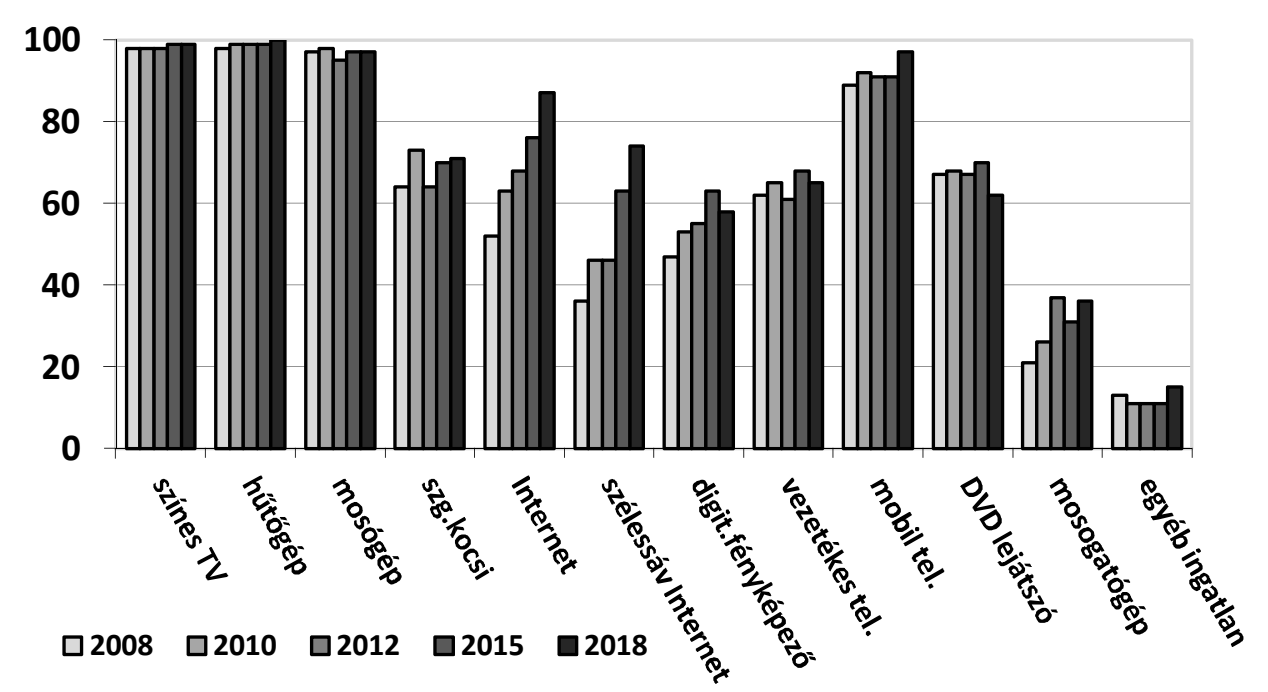

Forrás: Nyíregyháza Életminösége, 2008 - 2018

9. sz. diagram: Nyíregyházi lakások felszereltsége 2008 - 2018 (\%).

Az elmúlt tíz évben a mobiltelefon és az internethasználatra alkalmas eszközök bövülése tapasztalható a városlakóknál. Az informatikai-és internet hálózatfejlesztésnek köszönhetően növekszik az infokommunikációs eszközök, úgymint mobil telefon, laptop, tablet aránya. Az asztali számítógépnél enyhe csökkenés tapasztalható, valószínúleg más internetezésre és informatikai munkára alkalmas eszköz váltja ki annak birtoklását. ( 9 . sz. diagram)

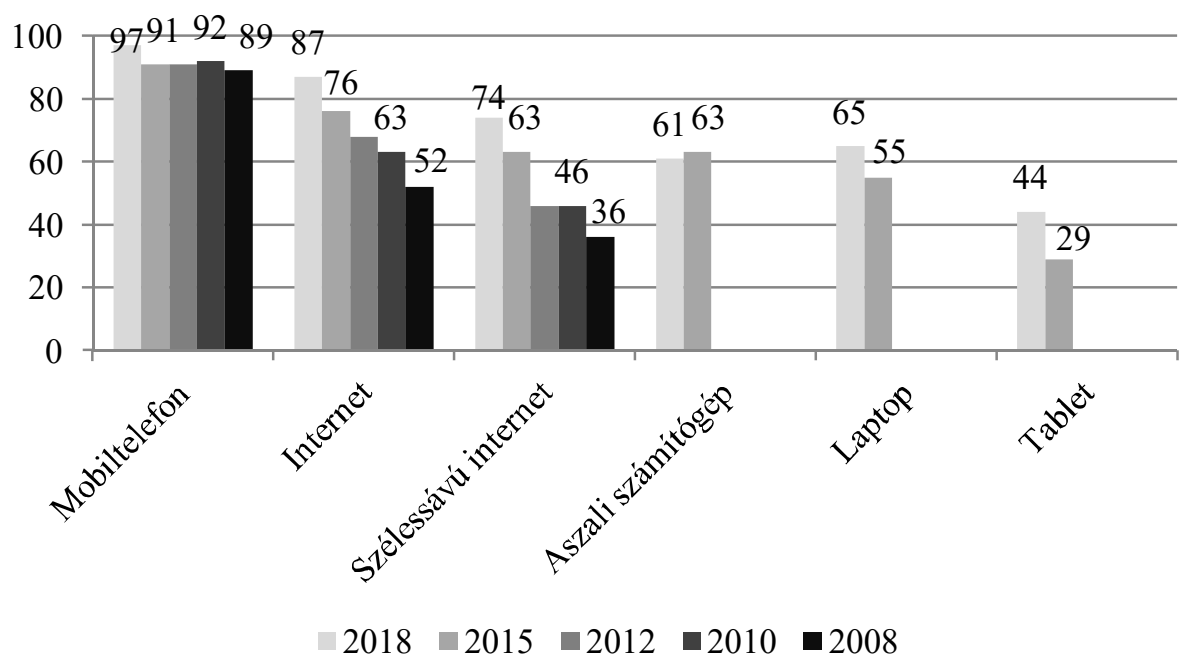

Forrás: Nyíregyháza Életminősége, 2008 - 2018

10. sz. diagram: mobileszközök és internet a háztartásokban 2008 és 2018 között. 
A városlakóknál a mobiltelefonálásra és internetezésre alkalmas eszközöket tekintve látványos fejlődés tapasztalható. Szinte minden városlakónak van mobiltelefonja és 87\%-ának van internetelérése. 2008 és 2018. között 35\%-kal növekedett az internettel rendelkezők aránya a városban. Vélhetően ez a bővülés az okos eszközök elterjedésének és a hálózatfejlesztésnek is köszönhetö. (10. sz. diagram)

\section{Összegzés}

2012-től mélypontra került az épített lakások száma, hiszen évente 8-9 ezer lakás épült az országban. Kismértékü, bizakodásra okot adó változás 2017-ben következett be, amikor az előző évhez képest kétharmadával növekedett az épített lakások száma, tényszerüen 14.389 lakás épült az országban ${ }^{6}$. Lakásállomány bővülés egyelőre nem tapasztalható az önkormányzatoknál. A lakásépítések száma városunkban is gyarapszik, a lakásárak dinamikusan növekednek, ami kedvezőtlen mindazoknak, akiknek jövedelmi és vagyoni helyzete nem teszi lehetővé a lakásvásárlást. Az albérletárak emelkedésével a piaci bérleményekből is egyre inkább kiszorulnak a társadalom alsó két jövedelmi tizedébe tartozók. A nyíregyházi lakásadatok rávilágítanak arra, hogy csökkenő önkormányzati lakásállomány mellett mindinkább növekszik a szociális lakásigénylők száma. A lakásárak megfizethetősége saját tulajdont, piaci lakásbérlést tekintve elérhetetlen a létminimum vagy az alatti jövedelemből élöknek. Az elszegényedő és szegénységben élő társadalmi csoportoknak reális és megfizethető lakhatási forma a szociális bérlakás lenne a kor színvonalának megfelelő minőségben. Az önkormányzati lakásállomány bővítése megkerülhetetlen, mivel a piaci szegmensekből kiszoruló lakástalanok, átmeneti és bizonytalan lakhatásban élők könnyen hajléktalanná válnak. Használaton kívüli önkormányzati lakások felújításával, új lakások építésével komfortossá és megfizethetővé lehet tenni a lakásokat, és megnövelni a ma még bizonytalan lakhatási helyzetben lévők lakhatáshoz jutásának reális esélyét.

A lakásban élő városlakók környezeti és felújítási gondjainak enyhítése környezetvédelmi ( $\mathrm{pl}$. zajszint csökkentése), rendészeti (pl. büncselekmények) és szociális intézkedések (pl. túzifa támogatás, lakásfelújítás szociális támogatása) átgondolását igényelik.

Egyértelmüen pozitív változás korunk informatikai és internetezésre alkalmas eszközeinek használata a háztartásokban. Az elmúlt évek helyi fejlesztéséinek köszönhetően a városlakók rendelkeznek mindazokkal az eszközökkel, melyek segítenek felhasználóvá válni a digitális világban.

\footnotetext{
${ }^{6}$ Lakás-és üdülőépítés (1960-). KSH, http://www.ksh.hu/docs/hun/xstadat/xstadat_hosszu/h_zrs001.html
} 


\section{Felhasznált irodalom}

1. Dóra I.; Hegedüs J.; Horváth Á.; Sápi Z.; Somogyi E.; Székely G. (2018): Miben élünk? A 2015. évi lakásfelmérés részletes eredményei. KSH, Látogatva: 2018. november 26. Letöltési hely: http://www.ksh.hu/docs/hun/xftp/idoszaki/pdf/miben_elunk15_2.pdf

2. Éves jelentés a lakhatási szegénységröl 2018. Habitat for Humanity, Látogatva: 2018. november 28. Letöltési hely: https://habitat.hu/mivel-foglalkozunk/ lakhatasi-jelentesek/lakhatasi-jelentes-2018/lakhatas-2018-adattar/

3. Huszti Éva, Hüse Lajos, Takács Péter, Fábián Gergely, (2018): A „Nyíregyháza Élet-minősége 2018" vizsgálat és a kutatás módszertana. Acta Medicinae et Sociologica Vol.9. No.27. 7-18.

4. Kovács Marcell szerk. (2018): Mikrocenzus 2016, 7. Lakáskörülmények. KSH, Látogatva: 2018. november 26. Letöltési hely: https://www.ksh.hu/docs/ hun/xftp/idoszaki/mikrocenzus2016/mikrocenzus_2016_7.pdf

5. Szoboszlai Katalin (2015): Lakásjellemzők a Nyíregyházi járásban és a megyeszékhelyen. Acta Medicinae et Sociologica, 6:(6) pp. 30-46.

6. Szoboszlai Katalin (2014): Lakásjellemzők Nyíregyházán 2012. In: Életminőség Nyíregyházán (szerkesztette: Huszti Éva, Patyán László, Fábián Gergely). Acta Medicinae et Sociologica, Vol. 5. No. 12 - 13. 2014

7. Szoboszlai Katalin (2012): Lakásjellemzők Nyíregyházán 2008-2010. In: Életminőség Nyíregyházán 2008-2010 (Szerk.: Fábián Gergely - Patyán László Huszti Éva) DE OEC Egészségügyi Kar, Nyíregyháza, 2012. p. 69-82.

\section{Internetforrások:}

1. https://www.ksh.hu/mikrocenzus2016/kotet_7_lakaskorulmenyek https://www.ingatlannet.hu/statisztika/Szabolcs-Szatm\%C3\%A1rBereg_megye

2. https://www.ingatlannet.hu/statisztika/Ny\%C3\%ADregyh\%C3\%A1za

3. https://habitat.hu/mivel-foglalkozunk/lakhatasi-jelentesek/lakhatasi-jelentes2018/hozzaferhetoseg-es-megfizethetoseg/ 